\title{
Genetic variability of bovine GHR, IGF-1 and IGFBP-3 genes in Indian cattle and buffalo
}

\author{
K.P. Ramesha $\#$, Akhila Rao, M. Basavaraju, G.R. Geetha, \\ M.A. Kataktalware \& S. Jeyakumar \\ Genetics Laboratory, Dairy Production Section, ICAR- SRS of NDRI, Adugodi, \\ Bengaluru-560030- India
}

(Received 1 December 2014; Accepted 6 September 2015; First published online 1 December 2015)

\begin{abstract}
Copyright resides with the authors in terms of the Creative Commons Attribution 2.5 South African Licence. See: http://creativecommons.org/licenses/by/2.5/za

Condition of use: The user may copy, distribute, transmit and adapt the work, but must recognise the authors and the South African Journal of Animal Science.
\end{abstract}

\begin{abstract}
The identification of genetic polymorphisms in the genes that play a crucial role in regulatiing growth and development of livestock enables us to evaluate the biological similarities and to acquire a better perspective of quantitative traits. The present study was undertaken to characterize genetic variability in the bovine growth hormone receptor (GHR), insulin-like growth factor 1 (IGF-1) and insulin-like growth factor binding protein 3 (IGFBP-3) genes among Bos indicus (Malnad Gidda, Khillar), Bos taurus (Holstein Friesian, Jersey) cattle and Asian water buffalo Bubalus bubalis (Murrah, Surti) using polymerase chain reactionsingle strand conformation polymorphism (PCR-SSCP) analysis. These polymorphisms were confirmed by direct sequencing. The comparative gene sequence analysis in cattle and buffalo breeds revealed 18 single nucleotide polymorphisms (SNPs) across different loci. Eight SNPs were detected in the bovine growth hormone receptor (GHR) gene, of which four were found in the promoter region and four in the exon 4 region. In the IGF-1 gene, two SNPs were observed in the 5'UTR, three SNPs in the intron 3 region and two SNPs in the coding region of exon 4. Three SNPs were detected in the exon 2 region of the bovine IGFBP-3 gene. The frequency of rare alleles observed in the present study ranged from 0.04 to 0.16 . The present results revealed high levels of genetic variability in the GHR, IGF-1 and IGFBP-3 genes in cattle and buffalo reared in India.
\end{abstract}

Keywords: PCR-SSCP, genetic polymorphism, cattle, buffalo

${ }^{\sharp}$ Corresponding Author: kpragb@gmail.com

\section{Introduction}

In dairy animals, growth and reproduction are two key traits to be considered for genetic improvement of production efficiency. Genetic markers for quantitative trait loci that are linked to the causal genes could be used to select animals for breeding programmes. The most effective markers are the functional mutations linked to the trait genes (Williams, 2005). Identification and use of markers for milk quality and production traits, disease resistance and thermo-tolerance would ensure better health and productivity (Singh et al., 2014).

Molecular techniques such as polymerase chain reaction-single strand conformation polymorphism (PCR-SSCP) are effective tools in the animal breeding domain for providing breeders an opportunity to identify and select superior animals based on genotypes associated with particular traits of interest (Bastos et al., 2001). Growth hormone receptor (GHR), IGF-1 and IGFBP-3 genes have been shown to regulate postnatal somatic growth and stimulate anabolic processes (Clemmons et al., 1987). Earlier research on GHR, IGF-1 and IGFBP-3 in cattle, goats and chickens showed genetic polymorphisms and their association with production traits (Pereira et al., 2005; Liu et al., 2010).

Growth hormone $(\mathrm{GH})$ is an anabolic hormone synthesized and secreted by the somatotroph cells, and plays an important role in postnatal longitudinal growth and development, tissue growth, lactation, reproduction, and protein, lipid and carbohydrate metabolism (Akers, 2006; Ayuk \& Sheppard, 2006; Thidar et al., 2008). Growth hormone exerts its influence on growth and metabolism through interaction with the GHRs on the surface of the target cells (Hradecka et al., 2008). Changes in the functional regions of GHR can affect its binding capacity and signalling pathway, and therefore alter the activity of $\mathrm{GH}$ in the target tissues (Olenski et al., 2010). Several polymorphisms of bovine GHR were described by Dybus \& Grzesiak (2006) and Kmiec et al. (2007). The growth promoting and metabolic actions of the $\mathrm{GH}$ are generally 
mediated by insulin-like growth factor I (IGF-I), which is a 70 amino-acid, single-chain polypeptide produced in the liver in response to $\mathrm{GH}$. Insulin-like growth factors (IGFs), their receptors and their binding proteins play key roles in regulating cell proliferation and apoptosis. IGFBP-3 is one of the proteins that bind to the IGFs. IGFBP-3 is a modulator of IGF bioactivity and a direct growth inhibitor in the extravascular tissue compartment. The gene encoding IGFBP-3 is highly expressed in the liver, where the bulk of the circulating protein originates, and it is also expressed in a highly regulated fashion. In addition, some of the IGFBPs, such as IGFBP-3 may possess intrinsic biological activity independent of any interaction with IGF (Valentinis et al., 1995).

Holstein Friesian and Jersey breeds were imported to India by state or central government departments to improve milk production of Indian cattle through upgrading/crossbreeding using artificial insemination technology. Khillar is a draught breed reared in northern Karnataka and Maharashtra states in India. The Malnad Gidda cattle are unique dwarf cattle, native to heavy rainfall areas of the Western Ghats and coastal region in Karnataka, India. These cattle are highly resistant to many diseases and have the ability to withstand stressful environmental conditions. They calve regularly and perform under stressful conditions on grazing (Ramesha et al., 2013). In India, the buffalo plays important roles in milk production and livelihood security of smallholder milk producers. In the Indian context, buffalo are preferred in many states for their adaptability to agro-climatic conditions, higher fat and milk production potential and being a good source of meat. Murrah buffalo is considered one of the best breeds for milk production and is found in Rohtak, Hisar, Jind and Gurgaon districts of Haryana. Murrah buffalo produce around $2000 \mathrm{~kg}$ of milk per lactation. This breed is used for upgrading local buffalo in many parts of Asia and other parts of the world. Surti buffalo are medium sized, rusty brown in colour, and are found in the Kheda and Vadodara districts of Gujarat. Surti buffalo produce around $1300-1500 \mathrm{~kg}$ of milk per lactation. Surti animals are smaller in size than Murrah buffalo and are being used for improving local buffalo in certain regions of Rajasthan and Karnataka.

Earlier researchers reported that GHR genes are important candidates for growth, carcass and milk traits in dairy cattle. It was showed that a significant correlation was found between the PI promoter of the bovine GHR gene and growth rates in young Angus cattle (Hale et al., 2000). Biswas et al. (2003) identified GH gene polymorphism in intron4/exon5 and its effect on birth weight in different breeds of cattle and buffalo. Rahbar et al. (2010) found polymorphism in the promoter region of the GHR gene and an association with milk-related traits in Holstein cows. In the GHR gene five polymorphisms were recorded in East Anatolian Red cattle, South Anatolian Red cattle and Turkish Grey cattle (Akad et al., 2012). Deepika \& Salar (2013) established polymorphism in exon 10 and the $5^{\prime}$ non-coding regions of Growth hormone receptor and its association with meat and milk-related traits in 10 indigenous grey cattle breeds. Siadkowska et al. (2006) observed the effect of polymorphism in the 5'-non-coding region of the IGF-I gene on production traits in Polish Holstein Friesian cattle. Mullen et al. (2011) identified a total of 16 SNPs in IGF-1 and GH gene and its association with milk production, body condition score and fertility traits in Holstein Friesian lactating dairy cows. Szewczuk et al. (2011) recorded associations between IGF-1/ Tas/ polymorphism in Polish Holstein Friesian cows and its association with milk traits and Nicolini et al. (2013) polymorphisms in the IGF-1 gene and its association with postpartum resumption of ovarian cyclicity in Holstein cows. Kim et al. (2005) identified novel SNPs in the bovine IGFBP-3 gene in Korean cattle. Choudhary et al. (2007) observed DNA polymorphisms of IGFBP-3 gene in HF and crossbred cattle and its association with birth weight and body weight. Othman et al. (2014) identified SNP in IGFBP-3 in Egyptian cattle.

Monomorphism at different loci of GHR gene was reported in Suti buffalo (Mamta \& Vataliya (2014a) and Meshana buffalo (2014 b). Fatima et al. (2009) identified three SNPs in IGF-I gene in three buffalo breeds of Gujarat. Eleven novel polymorphisms were also observed earlier for buffalo, that is, six in Egyptian water buffalo and five in Indian buffalo in the IGF-1 receptor. These SNPs were also associated with growth traits (El-Magd et al., 2013). Khederzadeh \& Yazdanpanah (2013) showed a low variability in the exon 1 region while observing a high degree of genetic diversity in the 5' Flanking Region of the IGF-1 gene in southern populations of Iranian buffalo. The present study aimed to identify and characterize polymorphisms in the promoter and coding regions of the GHR, IGF-1gene and a section of the IGFBP-3 genes among different breeds of cattle (Malnad Gidda, Khillar, Holstein Friesian and Jersey) and buffalo (Murrah and Surti) using PCR-SSCP technique.

\section{Materials and Methods}

Blood samples were collected from 216 males belonging to cattle (Bos indicus, Bos taurus) and buffalo breeds (Bubalus bubalis), maintained for breeding at livestock farms in Karnataka, India. The cattle breeds were Malnad Gidda $(n=42)$, Khillar $(n=36)$, Holstein Friesian $(n=30)$ and Jersey $(n=36)$, and the buffalo breeds were Murrah $(n=36)$ and Surti $(n=36)$. A blood sample $(8-10 \mathrm{~mL})$ from each male was collected aseptically by jugular veni-puncture using vacutainer tubes containing EDTA, and was stored at 
$4^{\circ} \mathrm{C}$ pending further processing. Within 24 hours of the collection of blood, genomic DNA was isolated by the high salt method as described by Miller et al. (1988) with minor modifications to the concentration of SDS, $\mathrm{NaCl}$ and EDTA added. Agarose gel electrophoresis and spectrophotometric methods were used to determine the quality, quantity and purity of DNA. The samples showing an optical density (OD) ratio $(260 / 280 \mathrm{~nm})$ of between 1.8 and 2.0 , were diluted to $100 \mathrm{ng} / \mathrm{\mu L}$, and stored at $-20^{\circ} \mathrm{C}$ until further analysis.

The PCR-SSCP analysis of the GHR, IGF-1 and IGFBP-3 genes was performed to assess the genetic variability of these genes and to identify polymorphisms in B. indicus (Malnad Gidda and Khillar), $B$. taurus (Holstein Friesian and Jersey) cattle and buffalo B. bubalis (Murrah and Surti). Based on the published nucleotide sequence information of the GHR-P gene (Gen bank accession number EF116490).

Primers as reported by Sharma et al. (2014) were procured to obtain the amplicons of GHR-P, GHRE, IGF-1 and IGFBP-3 regions. The primer sequences, the region covered by each primer, annealing temperature, amplicon size and reference Gene bank of the amplified fragments are shown in Table. 1.

Table 1 Primer sequence, the region covered by each primer, annealing temperature and amplicon size used in characterization of bovine GHR, IGF1 and IGFBP-3 genes

\begin{tabular}{|c|c|c|c|c|c|}
\hline Primer & $\begin{array}{l}\text { Region } \\
\text { covered }\end{array}$ & Sequence $\left(5^{\prime}-3^{\prime}\right)$ & $\begin{array}{c}\mathrm{Ta} \\
\left({ }^{\circ} \mathrm{C}\right)\end{array}$ & $\begin{array}{l}\text { Amplicon } \\
\text { size } \\
\text { (bp) } \\
\end{array}$ & $\begin{array}{c}\text { Gen bank } \\
\text { Accession } \\
\text { number }\end{array}$ \\
\hline GHR-P & Promoter & $\begin{array}{l}\text { F -ACTCAGTGGTGGGAATCAT } \\
\text { R -GTGTGGGGTTGGAGGAG }\end{array}$ & 60 & 682 & EF116490 \\
\hline GHR-E & Exon4 & $\begin{array}{l}\text { F -ATTACCCTCCTGATTTCATGACTTGT } \\
\text { R- CCAGCATCTAAAATAGTACCCAACA }\end{array}$ & 55 & 353 & AY739707 \\
\hline IGF1-A & 5' UTR & $\begin{array}{l}\text { F - GGCCAAGCAGCAGAGTAGAG } \\
\text { R- GGAAACAGCTGGGGGAAC }\end{array}$ & 61 & 623 & D26119 \\
\hline IGF1-B & Ex1//nt1 & $\begin{array}{l}\text { F- GGGAGAGAGAGAGAAGGCAAGC } \\
\text { R-CACACACACACCACACAGTCC }\end{array}$ & 63 & 748 & D26119 \\
\hline IGF1-C & Ex2/Int2 & $\begin{array}{l}\text { F-AACTGGCCAGGACTTTTGATTACA } \\
\text { R-CAGTTATTGGAAAGGCCGAAGTC }\end{array}$ & 58 & 423 & D26119 \\
\hline IGF1-D & Int2/Ex3 & $\begin{array}{l}\text { F-ATCCGTCCCTACCGCTTAGT } \\
\text { R-AGCCTGGGTAAACTGCCTTT }\end{array}$ & 61 & 682 & D26119 \\
\hline IGF1-E & Ex3/Int3 & $\begin{array}{l}\text { F-GCAGTTTACCCAGGCTCGTA } \\
\text { R-TATCCCCTCAGGAGTGCAAC }\end{array}$ & 52 & 711 & D26119 \\
\hline IGF1-Fa & Int3/Ex4 & $\begin{array}{l}\text { F-TTCCCCAAGGTTTCACAGTAGC } \\
\text { R-CAGGCAGTCATTCAGTTCTTCACA }\end{array}$ & 58 & 446 & D26119 \\
\hline IGF1-Fb & Int4/Ex5 & $\begin{array}{l}\text { F-CCTCCCTCTCGCTGCTCTGTG } \\
\text { R-GGGCGCTCTCCGACTGCTC }\end{array}$ & 61 & 456 & D26119 \\
\hline IGF1-G & Ex5/Int5 & $\begin{array}{l}\text { F-GGTGAGGATTGGCCATAGAC } \\
\text { R-CAACTTGGGGAGCTCTTTTG }\end{array}$ & 59 & 633 & D26119 \\
\hline IGF1-H & $\begin{array}{l}\text { Ex6/ } \\
\text { 3'UTR }\end{array}$ & $\begin{array}{l}\text { F-ATGTCATTTTTCTCCCTTATTTTTAG } \\
\text { R-CAAGCCTGCTGAATGAATGTC }\end{array}$ & 56 & 471 & D26119 \\
\hline $\begin{array}{l}\text { IGFBP- } \\
3\end{array}$ & Int1/Ex2 & $\begin{array}{l}\text { F-GAAATGGCAGTGAGTCGG } \\
\text { R-TGGGCTCTTGAGTAATGGTG }\end{array}$ & 54 & 316 & AF305712 \\
\hline
\end{tabular}

F: forward, R: reverse, $T_{a}$ : annealing temperature.

Polymarase Chain Reaction was performed in a volume of $25 \mu \mathrm{L}$ using $100 \mathrm{ng}$ of DNA, 200 $\mu \mathrm{M}$ dNTPs, $20 \mathrm{pM}$ of each primer and $1 \mathrm{U}$ of Taq DNA polymerase in $1 \times$ PCR buffer. The PCR cycling conditions included an initial denaturation step of $94^{\circ} \mathrm{C}$ for 5 min followed by $94{ }^{\circ} \mathrm{C}$ for $1 \mathrm{~min}$, specific annealing temperature for $1 \mathrm{~min}$ and elongation at $72^{\circ} \mathrm{C}$ for $1 \mathrm{~min}$. After $35 \mathrm{cycles}$, a final extension was given at $72^{\circ} \mathrm{C}$ for $5 \mathrm{~min}$. Samples were held at $4{ }^{\circ} \mathrm{C}$ until further use. PCR reactions were performed using the thermal cycler (CG Palm Cycler, Genetix, India). To check fragment integrity PCR products were electrophoresed at $100 \mathrm{~V}$ in a $1.5 \%$ agarose gel containing $0.5 \mu \mathrm{g}$ ethidium bromide/mL along with a DNA molecular size marker. The gels were visualized and documented with the Gel documentation system (Gel doc 1000, Bio-Rad, USA).

About $10 \mu \mathrm{L}$ of PCR products were further diluted with $10 \mu \mathrm{L}$ of denaturing solution (95\% formamide, $10 \mathrm{mM} \mathrm{NaOH}, 0.02 \%$ Xylene cyanol, $0.02 \%$ bromophenol blue and $20 \mathrm{mM}$ EDTA) and denatured at $94{ }^{\circ} \mathrm{C}$ for 10 minutes, followed by rapid chilling on ice for 20 minutes. Amplicons were resolved on a $10 \%$ acryl amide : bisacrylamide $(29: 1)$ PAGE gel. The electrophoresis was carried out in SCIE-PLAS, UK vertical 
electrophoresis unit using $1 \times$ TBE buffer for 6 hours (200 volts) at $4{ }^{\circ} \mathrm{C}$. The gels were silver stained as per the protocol of Sambrook \& Russel (2001). The PCR products, giving unique SSCP band patterns, were analysed by direct sequencing (Amnion Biosciences Pvt. Ltd., Bengaluru, India). Sequence data were analysed and manually checked using Bio-edit software for detecting SNPs by comparing observed sequences with the reference sequence (Hall, 1999). Analysis of identified SNPs in exonic region was done using ExPASy translate tool (webexpasy.org/translate/).

\section{Results}

Intron1/Exon2 of (IGFBP-3 exhibited two SSCP band patterns (Pattern I and Pattern II) in Malnad Gidda and Khillar, three SSCP band patterns (Pattern I, Pattern II and Pattern III) in Holstein Friesian and Jersey cattle, while it was found to be monomorphic in Murrah and Surti buffaloes. In Intron 3/Exon 4 of IGF1-Fa region Malnad Gidda and Khillar, Holstein Friesian and Jersey cattle exhibited two SSCP band patterns (Pattern I and Pattern II), while Murrah and Surti revealed three SSCP band patterns (Pattern I, Pattern II and Pattern III). Two types of SSCP band patterns (Pattern I and Pattern II) were observed in all the cattle and buffalo breeds screened for the promoter region of growth hormone receptor gene (GHR-P, Figure 1) and the 5' UTR region of IGF1-A. Exon4 (GHR-E) revealed two band patterns (Pattern I and Pattern II) in Malnad Gidda, Khillar, Holstein Friesian and Jersey cattle, whereas it was found to be monomorphic in Murrah and Surti buffaloes. All the cattle and buffalo breeds were found to be monomorphic for different regions of insulin-like growth factor, namely Exon 1/Intron 1 (IGF1-B), Exon 2/Intron 2 (IGF1-C), Intron 2/Exon 3 (IGF1-D), Exon 3/Intron 3 (IGF1-E), Intron 4/Exon 5 (IGF1-Fb) and Exon 5/Intron 5 (IGF1-G). In Exon 6, the 3'UTR (IGF1-H) region was found to be monomorphic in Malnad Gidda and Khillar, Murrah and Surti, whereas two SSCP band patterns were observed for Holstein Friesian and Jersey cattle. The genotypic frequency and SSCP band patterns for the GHR, IGF-1and IGFBP3 genes in the four breeds of cattle and two breeds of buffalo are summarized in Table 2. The genotypic frequencies of rare alleles found among the breeds were $0.04,0.08,0.12$ and 0.16 , respectively.

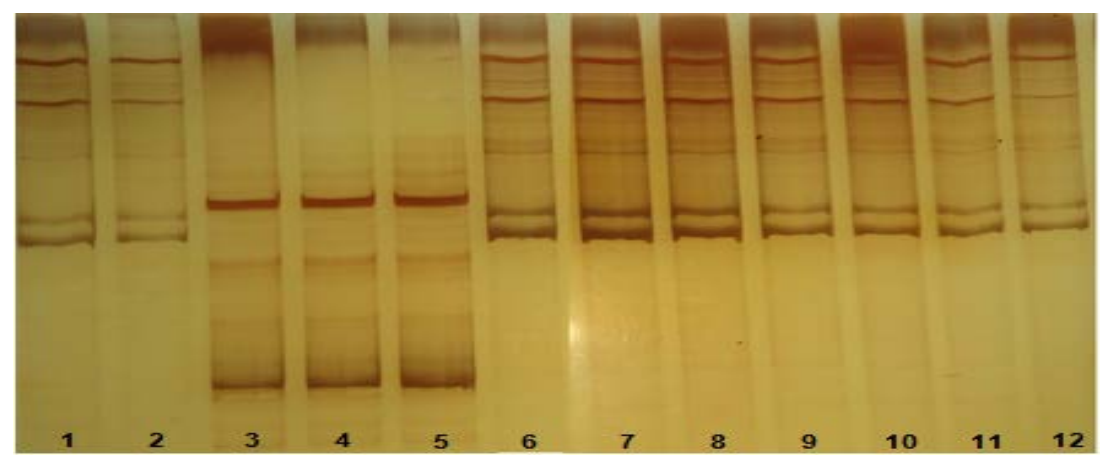

Figure 1 PCR- SSCP band patterns in the promoter region of bovine GHR-P gene in Malnad Gidda cattle Lanes 1-2, 6-12 showing pattern 1 and Lane-3-5 showing pattern 2.
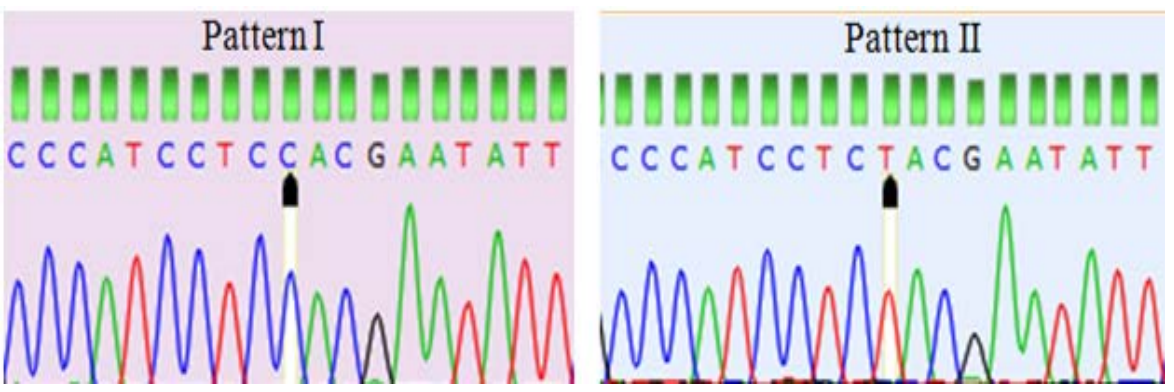

Figure 2 Sanger's trace figure showing comparison of Pattern I and Pattern II genotypes of the bovine IGF1A gene.The arrow showing $C \rightarrow T$ transition at base position 1627 in Jersey breed. 
Table 2 Genotypic frequency of different SSCP band patterns of growth hormone receptor (GHR) and insulin-like growth factor 1 (IGF-1) and insulin-like growth factor binding protein 3 (IGFBP-3) genes in Bos indicus, Bos taurus and Bubalus bubalis breeds

\begin{tabular}{|c|c|c|c|c|c|c|c|c|c|}
\hline $\begin{array}{l}\text { Gene } \\
\text { fragment }\end{array}$ & Breed & $\begin{array}{c}\text { Band } \\
\text { pattern }\end{array}$ & GF & Breed & $\begin{array}{c}\text { Band } \\
\text { pattern }\end{array}$ & GF & Breed & $\begin{array}{c}\text { Band } \\
\text { pattern }\end{array}$ & GF \\
\hline \multirow{2}{*}{ GHR_P } & \multirow{2}{*}{ MG \&KR } & 1 & 0.35 & \multirow{2}{*}{ HF \& JY } & I & 0.28 & \multirow{2}{*}{ MR \& SR } & I & 0.50 \\
\hline & & II & 0.65 & & II & 0.72 & & II & 0.50 \\
\hline \multirow{2}{*}{ GHR_E } & \multirow{2}{*}{ MG \&KR } & 1 & 0.25 & \multirow{2}{*}{ HF \& JY } & 1 & 0.15 & \multirow{2}{*}{$M R \& S R$} & \multirow{2}{*}{$\mathrm{M}-$} & \\
\hline & & II & 0.75 & & II & 0.85 & & & \\
\hline \multirow{2}{*}{ IGF1_A } & \multirow{2}{*}{ MG \&KR } & 1 & 0.67 & \multirow{2}{*}{ HF \& JY } & I & 0.92 & \multirow{2}{*}{ MR \& SR } & I & 0.63 \\
\hline & & II & 0.33 & & II & 0.08 & & II & 0.37 \\
\hline \multirow{3}{*}{ IGF1_Fa } & \multirow{3}{*}{ MG \&KR } & 1 & 0.84 & \multirow{3}{*}{ HF \& JY } & 1 & 0.88 & \multirow{3}{*}{ MR \& SR } & 1 & 0.80 \\
\hline & & II & 0.16 & & II & 0.12 & & II & 0.04 \\
\hline & & & & & & & & III & 0.16 \\
\hline \multirow{2}{*}{ IGF1_H } & \multirow{2}{*}{ MG \&KR } & \multirow{2}{*}{ M } & \multirow{2}{*}{-} & \multirow{2}{*}{ HF \& JY } & 1 & 0.88 & \multirow{2}{*}{ MR \& SR } & \multirow{2}{*}{$M-$} & \\
\hline & & & & & II & 0.12 & & & \\
\hline \multirow{3}{*}{ IGFBP-3 } & \multirow{3}{*}{ MG \&KR } & 1 & 0.20 & \multirow{3}{*}{$\mathrm{HF} \& \mathrm{JY}$} & 1 & 0.26 & \multirow{3}{*}{ MR \& SR } & \multirow{3}{*}{$M-$} & \\
\hline & & \multirow{2}{*}{ II } & \multirow{2}{*}{0.80} & & II & 0.62 & & & \\
\hline & & & & & III & 0.12 & & & \\
\hline
\end{tabular}

MG: Malnad Gidda; KR: Khillar; HF: Holstein Friesian; JY: Jersey; MR: Murrah; SR: Surti; GF: genotypic frequency; M: monomorphic band pattern.

The samples showing differential band patterns in duplicate were subjected to sequencing. The sequences obtained for fragments of GHR-P (Accession No: HG738857, HG738858, HG738859), GHR-E (Accession No: HG738860, HG738861, HG738862), IGF-1 (Accession No: HG797641, HG797642, HG797643, HG797644, HG797645, HG797646, HG797647, HG797648, HG797649) and IGFBP-3 (Accession No: HG738863, HG738864, HG738865) have been submitted to the EMBL database. Comparative sequence analysis of GHR, IGF-1 and IGFBP-3 fragments in different cattle and buffalo breeds revealed 18 SNPs. Eight SNPs were detected in bovine growth hormone receptor (GHR), of which four SNPs were found in the promoter region (T187C, C271T, T336G and A412C) and four other SNPs in the exon 4 region. Exon 4 of GHR gene exhibited two transversions (A105T, A352T) and two transition

Table 3 Single nucleotide polymorphisms (SNPs) detected in a bovine GHR gene in cattle and buffalo breeds

\begin{tabular}{llllll}
\hline Region & Gene & Position $^{\text {a }}$ & Breed & Mutation & Amino acid change \\
\hline \multirow{4}{*}{ Promoter } & GHR & T187C & Khillar, Malnad Gidda \& Murrah & Transition & Leucine (no change) \\
& GHR & C 271T & Holstein Friesian & Transition & Proline (no change) \\
& GHR & T336G & Malnad Gidda,Khillar & Transversion & Alanine (no change) \\
Exon 4 & A412C & Murrah & Transversion & Aspartate to alanine \\
\hline & GHR & A105T & Holstein Friesian, Jersey & Transversion & Lysine (no change) \\
& GHR & T226C & Holstein Friesian, Jersey & Transition & Leucine to proline \\
& GHR & T246C & Malnad Gidda, Khillar & Transition & Phenylalanine to serine \\
& GHR & A352T & Surti & Transversion & Leucine to phenylalanine
\end{tabular}

\footnotetext{
${ }^{a}$ Based on genebank sequence EF116490 and AY739707, common nucleotide followed by the variant is shown in case of bovine GHR gene.
} 
mutations (T226C, T246C). A105T was found to be synonymous, whereas T226C and T246C and A352T SNPs were non-synonymous, and showed amino acid change from leucine to proline, phenylalanine to serine and leucine to phenylalanine respectively (Table 3).

Seven SNPs were identified in Bovine IGF-1 and three SNPs in Bovine IGFBP-3 gene (Table 4). In IGF-1 gene, two SNPs in 5'UTR (T1547G, C1627T) was observed in Jersey and Murrah breed (Figure. 2), three in the intron3 region (G4619A, A4728C, T4638A) and two SNPs (G4770T and A4858T) were observed in coding region of exon 4 in Murrah and Surti buffaloes which resulted in synonymous mutations. Three SNPs at G7886T (alanine to serine), A7927G and T8069C were found in the non-coding region of the exon2 region of the bovine IGFBP-3 gene, respectively (Figure 3).

Table 4 Single nucleotide polymorphisms detected in IGF-1 and IGFBP-3 gene in cattle and buffalo breeds

\begin{tabular}{llllll}
\hline Region & Gene & Position $^{\text {a }}$ & Breed & Mutation & Amino acid change \\
\hline \multirow{2}{*}{ 5' UTR } & IGF1 & T1547G & Jersey, Murrah & Transversion & Methionine to arginine \\
& IGF1 & C1627T & Jersey, Murrah & Transition & Serine (no change) \\
\hline \multirow{2}{*}{ Intron3 } & IGF1 & G4619A & Holstein Friesian, Jersey & Transition & Non-coding \\
& IGF1 & A4728C & Malnad Gidda, Khillar & Transversion & Non-coding \\
& IGF1 & T4638A & Jersey, Surti & Transversion & Non-coding \\
\hline \multirow{2}{*}{ Exon 4 } & IGF1 & G4770T & Murrah, Surti & Transversion & Valine to leucine \\
& IGF1 & A4858T & Murrah, Surti & Transversion & Aspartate to leucine \\
\hline \multirow{2}{*}{ Exon2 } & IGFBP-3 & G7886T & Holstein Friesian, Jersey & Transversion & Alanine to serine \\
& IGFBP-3 & A7927G & Holstein Friesian, Jersey & Transition & Proline (no change) \\
& IGFBP-3 & T8069C & Holstein Friesian, & Transversion & Non-coding
\end{tabular}

${ }^{a}$ Based on genebank sequence D26119 and AF305712, common nucleotide followed by the variant is shown in the IGF-1 and IGFBP-3 gene.
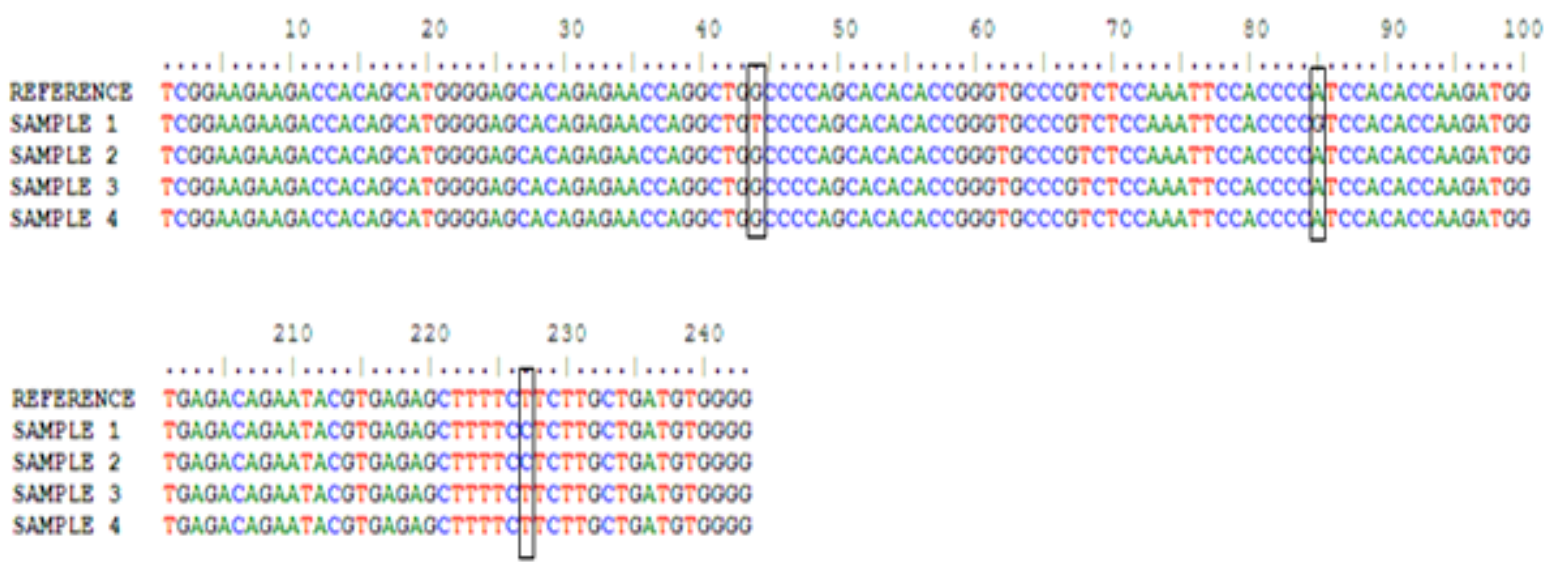

Figure 3 Multiple sequence alignment of IGFBP-3 gene covering Intron1/Exon2 region showing three single nucleotide polymorphisms in samples of cattle breeds by Bio-edit software.

Reference sequence covering from position 7843 to 8085 (Genbank Accession No. AF305712).

Sample 1 and 2: Jersey and Malnad Gidda cattle; Sample 3 and 4: Holstein Friesian and Khillar cattle.

\section{Discussion}

In India the dairy sector plays a vital role in the national economy by providing employment and income-generating opportunities for resource-poor farmers and landless labourers. PCR-SSCP analysis allows the detection of sequence changes that lead to mobility differences of single-stranded DNA molecules. In the present study, using PCR-SSCP analysis and a direct sequencing approach, 18 
polymorphic sites were detected in GHR, IGF-1 and IGFBP-3 genes in B. indicus (Malnad Gidda, Khillar), $B$. taurus (Holstein Friesian, Jersey) cattle and B. bubalis (Murrah, Surti) buffalo reared in India.

Eight SNPs were detected in bovine GHR, of which four SNPs were found in the promoter region (T187C, C271T, T336G and A412C) and four in the exon 4 region. Exon 4 of the GHR gene exhibited two transversions (A105T, A352T) and two transition mutations (T226C, T246C), indicating a high degree of genetic polymorphism in cattle and buffalo breeds under study in the chosen candidate genes. A105T was found to be synonymous, whereas T226C, T246C and A352T SNPs were non-synonymous and showed an amino acid change from leucine to proline, phenylalanine to serine and leucine to phenylalanine, respectively. Earlier reports on the characterization and genetic variability analysis of GHR, IGF-1 and IGFBP-3 genes in cattle and goats revealed a high degree of genetic variation, which is in accordance with this study. Hale et al. (2000 a) reported that GHR genes are important candidate genes for growth, carcass and milk traits in dairy cattle, and indicated a significant correlation between the length of the variable TG-repeat in the P1 promoter of the bovine GHR gene and growth rates in young Angus cattle. Biswas et al. (2003a) observed GH gene polymorphism in intron4/exon5 and its effect on birth weight in cattle (Sahiwal, Holstein Friesian, Jersey and crossbred cattle) and buffalo (Murrah, Bhadwari, Jaffarbadi, Nagpuri and Surti). Rahbar et al. (2010) showed the association of genotypes in the promoter region of the GHR gene with milkrelated traits in Holstein cows. Akad et al. (2012) detected five polymorphisms in the GHR gene in East Anatolian Red cattle, South Anatolian Red cattle and Turkish Grey cattle. Polymorphism in exon 10 and the $5^{\prime}$ non-coding regions of GHR gene and its association with meat and milk related traits in 10 indigenous grey cattle breeds were reported by Deepika \& Salar (2013). In IGF1 gene, the authors observed a high degree of genetic variability in the form of two SNPs in 5'UTR (T1547G, C1627T) in Jersey and Murrah breed, three in the intron 3 region (G4619A, A4728C, T4638A) in cattle and buffalo breeds, and two SNPs (G4770T and A4858T) were observed in the coding region of exon 4 in Murrah and Surti buffalo. Siadkowska et al. (2006) observed a correlation between the polymorphism in the 5'-non-coding region of the IGF-I gene and meat and milk production traits in Polish Holstein Friesian cattle. Mullen et al. (2011) identified 16 SNPs, which included 10 SNPs spanning the intronic and 3' regions of IGF-1 and six SNPs from 5' region of GH1 that were associated with lactation and fertility in Holstein Friesian lactating dairy cows. The transversion of $A \rightarrow C$ in the P1 promoter region of bovine IGF1 gene at position 977 bp upstream from the start codon in exon 1 was identified in Polish Holstein Friesian cows and statistically significant differences between individuals of different IGF-1/Tasl genotypes were found in milk, fat and protein yield (Szewczuk et al., 2011). Polymorphism in the IGF-1 gene was observed to be associated with postpartum resumption of ovarian cyclicity in Holstein cows (Nicolini et al., 2013). In a genetic polymorphism study of the IGF-I gene, three SNPs were detected in three buffalo breeds of Gujarat (Fatima et al., 2009) and six and five novel polymorphisms in Egyptian water buffalo and Indian buffalo, respectively, in the IGF-1 receptor gene and these SNPs were associated with growth traits (El-Magd et al., 2013). Khederzadeh \& Yazdanpanah (2013) reported a low variability in the exon 1 region, while observing a high degree of genetic diversity in the $5^{\prime}$ flanking region of the IGF-1 gene in southern populations of Iranian Buffalo.

Three SNPs at G7886T A7927G and T8069C were found in the non-coding region of exon2 of bovine IGFBP-3 gene, respectively. Kim et al. (2005) identified novel SNPs in the bovine IGFBP-3 gene in Korean cattle. DNA polymorphism of IGFBP-3 gene in HF and crossbred cattle and its association with birth weight and body weight was observed by Choudhary et al. (2007). Gao et al. (2009) observed that polymorphism in IGFBP-3 locus was associated with rump width and heart girth in Chinese beef cattle. Othman et al. (2014) reported SNP in IGFBP-3 in Egyptian cattle. Similar to our findings in buffalo, Padma et al. (2004) reported non-polymorphic nature of restriction sites in IGFBP-3 gene screened for Murrah, Surti, Jaffarabadi and Nagpuri breeds of Indian riverine buffalo.

Earlier researchers identified nine SNPs in exon 2 in the IGFBP-3 gene of Gayal (Bos frontalis), revealing high levels of genetic variability and also found an association between the SNPs and low fat content and rapid growth (Dongmei et al., 2012). The PCR-SSCP analysis of the $5^{\prime}$ flanking region of the goat IGF-1 gene in two breeds of goats reared in Iran revealed a novel SNP variation, which was associated with growth traits and yearling fleece weight (Kurdistani et al., 2013). Our study confirmed a high degree of genetic variability in GHR and IGF-1 genes in both cattle and buffalo. While genetic variability in IGFBP-3 was high in cattle, polymorphism in the buffalo breeds under study was not observed in the present study.

\section{Conclusion}

The polymorphisms identified in the bovine GHR gene, IGF-1 gene and the IGFBP-3 genes indicated a high level of genetic variability and further studies could be initiated in order to identify their potential as genetic markers associated with performance traits in cattle and buffalo. 


\section{Acknowledgements}

The authors are grateful to the Project Director, KLDA, and the Director, ICAR-National Dairy Research Institute for providing facilities to carry out this research work. This work was supported by Karnataka Livestock Development Agency (KLDA), Government of Karnataka, India, under the project entitled "Evaluation and improvement of indigenous cattle of Malnad region of Karnataka".

\section{References}

Akad, I.A., Mengi, A. \& Oztabak, K.O., 2012. A determination of growth hormone receptor gene polymorphisms in East Anatolian Red cattle, South Anatolian Red cattle, and Turkish Grey cattle. Turk. J. Vet. Anim. Sci. 36 (1), 27-33.

Akers, R.M., 2006. Major advances associated with hormone and growth factor regulation of mammary growth and lactation in dairy cows. J. Dairy Sci. 89, 1222-1234.

Ayuk, J. \& Sheppard, M.C., 2006. Growth hormone and its disorders. Postgrad. Med. J. 82 (963), 24-30.

Bastos, E., Alfredo, C., Azevedo, J. \& Pinto, H.G., 2001. Single strand conformation polymorphism (SSCP) detection in six genes in Portuguese indigenous sheep breed "Churra da Terra Quente". Biotechnol. Agron. Soc. Environ. 5 (1), 7-15.

Biswas, T.K., Bhattacharya, T.K., Narayan, A.D., Badola, S., Kumar, P. \& Sharma, A., 2003. Growth hormone gene polymorphism and its effect on birth weight in cattle and buffalo. Asian Australas. J. Anim. Sci. 16, 494-497.

Choudhary, V., Kumar, P., Bhattacharya, T.K., Bhushan, B., Sharma, A. \& Shukla, A., 2007. DNA polymorphism of insulin-like growth factor binding protein 3 gene and its association with birth weight and body weight in cattle. J. Anim. Breed. Genet. 124, 29-34.

Clemmons, D.R., Dehoff, M., McCusker, R., Elgin, R. \& Busby, W., 1987. Therole of insulin-like growth factor 1 in the regulation of growth. J. Anim. Sci. 65, 168-179.

Deepika \& Salar, R.K., 2013. Polymorphism studies of Growth hormone receptor (GHR) gene in indigenous Grey cattle breeds of India. Intl. J. Biomed. Life Sci. 4 (2), 270-277.

Dongmei, X., Min, W., Yueyuan, F., Qing, L., Jing, L., Xiao, G., Huaming, M. \& Weidong, D., 2012. Polymorphisms of the insulin-like growth factor-binding protein 3 gene (IGFBP3) in gayal (Bos frontalis). Gene 497, 98-102.

Dybus, A. \& Grzesiak, W., 2006. GHRH/Haelll gene polymorphism and its associations with milk production traits in Polish Black-and-White cattle. Arch. Tierz. Dummerstorf. 49 (5), 434-438.

El-Magd, M.A., Abbas, H.E., Kattawy, A.M. \& Mokhbatly, A., 2013. Novel polymorphisms of the IGF1R gene and their association with average daily gain in Egyptian buffalo (Bubalus bubalis). Domest. Anim. Endocrin. 45, 105-110.

Fatima, S., Bhatt, S.M., Bhong, C.D., Rank, D.N. \& Joshi, C.G., 2009. Genetic polymorphism study of IGF-I gene in buffaloes of Gujarat. Buffalo Bulletin 28 (3), 159-164.

Gao, X., Shi, M., Xu, X., Li, J., Renhong, Y. \& XuShang, Z., 2009. Sequence variations in the Bovine IGFlandIGFBP-3 genes and their association with growth and development traits in Chinese beef cattle. Agric. Sci. China 8 (6), 717-722.

Hale, C.S., Herring, W.O., Shibuya, H., Lucy, M.C., Lubahn, D.B. \& Keisler, D.H., 2000. Decreased growth in Angus steers with a short TG-microsatellite allele in the P1 promoter of the growth hormone receptor gene. J. Anim. Sci. 78, 2099-2104.

Hall, T.A., 1999. Bioedit: A user-friendly biological sequence alignment editor and analysis program for windows 95/98/NT. Nucleic. Acids. Symp. Ser. 41, 95-98.

Hradecka, E., Citek, J., Panicke, L., Rehout, V. \& Hanusova, L., 2008. The relation of GH1, GHR and DGAT1 polymorphisms with estimated breeding values for milk production traits of German Holstein sires. Czech J. Anim. Sci. 53 (6), 238-245.

Khederzadeh, S. \& Yazdanpanah, A., 2013. Polymorphisms in the $5^{\prime}$ flanking region and first exon of insulinlike growth factor 1 gene in southern populations of buffalo. Am. J. Biochem. Biotechnol. 9, 348-354.

Kim, J.Y., Yoon, D.H., Park, B.L., Kim, L.H., Na, K.J., Choi, J.G., Cho, C.Y., Lee, H.K., Chung, E.R., Sang, B.C., Cheong, I.J., Oh, S.J. \& Shin, H.D., 2005. Identification of novel SNPs in Bovine Insulin-like growth factor binding protein-3 (IGFBP-3)gene. Asian Australas. J. Anim. Sci. 18, 3-7.

Kmiec, M., Kowalewska-Luczak, I., Kulig, H., Terman, A., Wierzbicki, H. \& Lepczynski, A., 2007. Associations between $\mathrm{GHRH} /$ Haelll restriction polymorphism and milk production traits in a herd of dairy cattle. J. Anim. Vet. Adv. 6, 1298-1303.

Kurdistani, Z.K., Rostamzadeh, J., Rashidi, A. \& Davis, M.E., 2013. Evaluation of insulin-like growth factor-I gene polymorphism ongrowth traits and yearling fleece weight in goats. Small Rumin. Res. 111, 10-15. 
Liu, W.J., Fang, G.X., Fang, Y., Tian, K.C., Huang, X.X., Yao, X.K., Wang, M., Yu, H., Huang, Y.Z., Xin, J.J., Xin, Y.P., Yu, S.G. \& Chen, H., 2010. The polymorphism of a mutation of IGF1 gene on two goat breed of China. J. Anim. Vet. Adv. 9, 790-794.

Mamta, J. \& Vataliya, P.H., 2014b. Molecular study of growth hormone and growth hormone receptor genes in Mehsana buffalo. Ind. J. Vet. Anim. Sci. Res. 43 (4), 261-266.

Miller, S.A., Dykes, D.D. \& Polesky, H.F., 1988. A sample salting out procedure for extracting DNA from human nucleated cells. Nucleic Acids Res. 16, 1215.

Mullen, M.P., Lynch, C.O., Waters, S.M., Howard, D.J., Boyle, P.O., Kenny, D.A., Buckley, F., Horan, B. \& Diskin, M.G., 2011. Single nucleotide polymorphism in the growth hormone and insulin-like growth factor-I genes are associated with milk production, body condition score and fertility traits in dairy cows. Genet. Mol. Res. 10, 1819-1830.

Nicolini, P., Carriquiry, M. \& Meikle, A., 2013. A polymorphism in the insulin-like growth factor 1 gene is associated with postpartum resumption of ovarian cyclicity in Holstein-Friesian cows under grazing conditions. Acta. Vet. Scand. 55, 1-8.

Olenski, K., Suchocki, T. \& Kaminski, S., 2010. Inconsistency of associations between growth hormone receptor gene polymorphism and milk performance traits in Polish Holstein-Friesian cows and bulls. Anim. Sci. Papers Rep. 28 (3), 229-234.

Othman, O.E., Alam, S.S. \& Abd El-Aziem, S.H., 2014. Single nucleotide polymorphism in Egyptian cattle insulin-like growth factor binding protein-3 gene. J. Genet. Engineering Biotechnol. 12, 143-147.

Padma, B., Pushpendra Kumar., Choudhary, V., Dhara, S.K., Mishra, A., Bhattacharya, B.T.K., Bhushan \& Arjava Sharma, 2004. Nucleotide Sequencing and PCR-RFLP of Insulin-like Growth Factor Binding Protein-3 Gene in Riverine Buffalo (Bubalus bubalis). Asian Australas. J. Anim. Sci. 17, 910-913.

Pereira, A.P., Alencar, M.M.D., Oliveira, H.N.D. \& Regitano, L.C.D.A., 2005. Association of GH and IGF-1 polymorphisms with growth traits in synthetic beef cattle breed. Genet. Mol. Biol. 28 (2), 230-236.

Rahbar, R., Rahimi, G., Ansari Pirsaraei, Z. \& Gholizadeh, M., 2010. Identification of polymorphism in the promoter region of growth hormone receptor (GHR) gene and its association with milk-related traits in Holstein cows. Afr. J. Biotechnol. 9 (33), 5460-5464.

Ramesha, K.P., Jeyakumar, S., Kataktalware, M.A., Das, D.N. \& Nagaraju, K.M., 2013. Geographical distribution present, status and characteristics and haemotology of Malnad Gidda cattle - An Unique drawf cattle of Western Ghats in Karnataka. Biodiversity documentation and taxonomy (Indian Biodiversity Congress) 1, 429-434.

Sambrook, J. \& Russell, D.W., 2001. Molecular Cloning: A Laboratory Manual. Cold Spring Harbor Laboratory, New York.

Sharma, A., Dutt G., Jayakumar, S., Saroha V. \& Dixit, S.P., 2014. Sequence characterization and genetic variability analysis of GHR, IGF1 and IGFBP-3 genes in nine Indian goat breeds. J. App. Anim. Res. 42, 361-365.

Siadkowska, E., Zwierzchowski, L., Oprzadek, J., Strzalkowska, N., Bagnicka, E. \& Krzyzewski, J., 2006. Effect of polymorphism in IGF-I gene on production traits in Polish Holstein-Friesian cattle. J. Anim. Sci. 24, 225-237.

Singh, U., Deb, R., Alyethodi, R.R., Alex, R., Kumar, S., Chakraborty, S., Dhama, K. \& Sharma, A., 2014. Molecular markers and their applications in cattle genetic research: A review. Biomarkers and Genomic Medicine 6, 49-58.

Szewczuk, M., Zych, S. \& Czerniawska-Piatkowska, E., 2011. Association between IGF1/Tas/ polymorphism and milk traits of Polish Holstein Friesian cows. Archiv. Tierzucht. 54, 10-17.

ThidarMyint, H., Yoshida, H., Ito, T., He, M., Inoue, H. \& Kuwayama, H., 2008. Combined administration of ghrelin and GHRH synergistically stimulates $\mathrm{GH}$ release in Holstein preweaning calves. Domest. Anim. Endocrin. 34, 118-123.

Valentinis, B., Bhala, A., DeAngelis, T., Baserga, R. \& Cohen, P., 1995. The human insulin-like growth factor (IGF) binding protein-3 inhibits the growth of fibroblasts with a targeted disruption of the IGF-I receptor gene. Mol. Endocrinol. 9, 361-367.

Williams, J.L., 2005. The use of marker-assisted selection in animal breeding and biotechnology. Rev. Sci. Tech. Int. Epiz. 24 (1), 379-391. 